\title{
AL-QANDĀ $\bar{A}$
}

PERADILAN dan HUKUM KELUARGA ISLAM

\section{Tinjauan Hukum Islam terhadap Musyawarah dalam Penyelesaian Sengketa Ekonomi Syariah}

Islamic Law Review on Deliberations in the Shariah Economic Dispute Settlement

Musyfikah Ilyas

Dosen Fakultas Syariah dan Hukum UIN Alauddin Makassar

Email: musyfikah.ilyas@uin-alauddin.ac.id

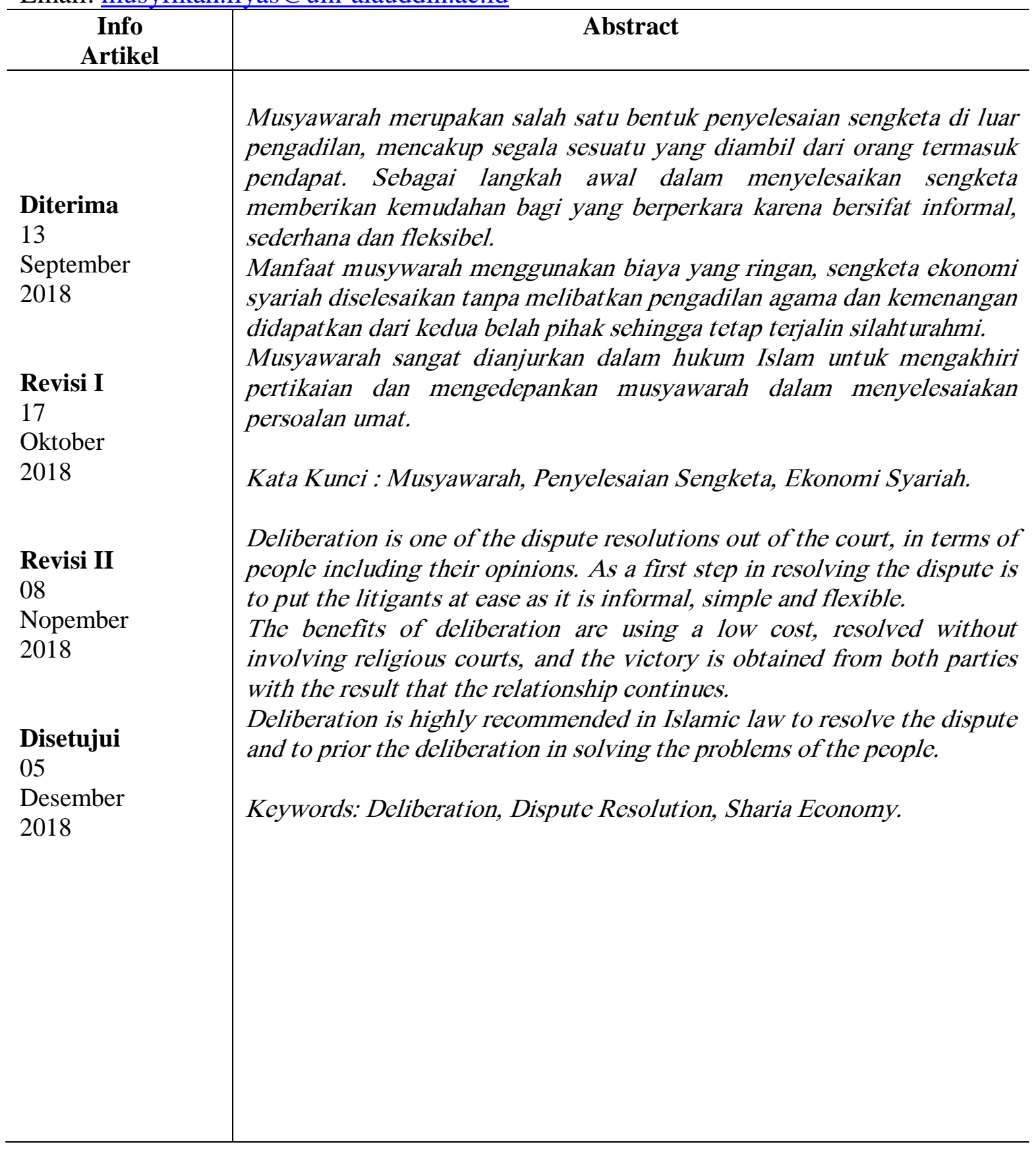




\section{A. PENDAHULUAN}

Ekonomi Syariah merupakan bagian dari sistem perekonomian Syariah, memiliki karakteristik dan nilai-nilai yang berfokus pada amar makruf nahi mungkar dan diantaranya adalah karakteristik ekonomi Ilāhiyyah, ahlak, kemanusiaan, keadilan, dan keseimbangan, ${ }^{1}$ mewujudkan integritas muslim yang kaffah dan menguntungkan pemberdayaan ekonomi umat.

Para pakar ekonomi syariah menjelaskan seperti pendapat Muhammad Baqir As-Sadr bahwa suatu cara atau jalan yang dipilih oleh Islam dalam rangka mencapai kehidupan ekonominya dan dalam memecahkan masalah ekonomi praktis sejalan dengan konsepnya tentang keadilan., ${ }^{2}$ sedangkan menurut Muhammad Abdul Mannan ${ }^{3}$ ekonomi Islam sebagai ilmu sosial yang mempelajari masalah-masaah ekonomi bagi suatu masyarakat yang diilhami oleh nilai-nilai Islam, adapun Muhammad Najetullah Siddiqi menjelaskan bahwa ekonomi syariah adalah respon terhadap tantangan ekonomi pada masa tertentu dan usaha keras dilakukan dengan merujuk kepada alQuran, Sunnah, Akal, Ijtihad dan Pengalaman., ${ }^{4}$ sedangkan pendapat Monzer Kahf bahwa sistem ekonomi syariah bagian dari agama, pencapaian falah, peranan yang sangat positif dari negara., ${ }^{5}$ Umer Chapra menyetakan bahwa kebijakan dalam suatu pembangunan ekonomi adalah memberikan kenyamanan, mengurangi konsentrasi kepemilikan, rekontruksi ekonomi, restrukturisasi finansial dan perencanaan kebijakan strategis., ${ }^{6}$ sedangkan Hasanuz Zaman, menyatakan pengetahuan dan penerapan hukum syariah untuk mencegah terjadinya ketidakadilan atas pemanfaatan dan pengembangan sumber-sumber materiil dan tujuan untuk memberikan kepuasan manusia dan melakukannya sebagai kewajiban kepada Allah swt. dan masyarakat. ${ }^{7}$ Dari beberapa defenisi, penjelasan dan kebijakan yang dilakukan oleh pakar ekonomi tentang ekonomi syariah adanya korelasi yang sama pada setiap pendapat yakni bermuara pada prinsip yang Islami.

Perkembangan ekonomi syariah dalam berbagai sektor terutama sektor regulasi tidak bisa terbantahkan, seiring perkembangan ekonomi syariah membutuhkan pondasi yang kukuh, oleh karenanya dibutuhkan pemahaman ekonomi syariah secara komprehensif. Di Indonesia pada Tahun 2016 lahirnya Peraturan Mahkamah Agung Nomor 14 Tahun 2016 tentang Tata Cara Penyelesiaan Sengketa Ekonomi Syariah tentunya memiliki prospek kedepan dalam menyelesaikan sengketa ekonomi syariah.

${ }^{1}$ Zainuddin Ali, Hukum Ekonomi Syariah (Cet. II; Jakarta: Sinar Grafika, 2008), h. 3

${ }^{2}$ M. Aslam Haneef, Pemikiran Ekonomi Islam Kontemporer (Jakarta: Rajawali Press, 2010).

${ }^{3}$ M. Abdul Mannan, The Making of An Islamic Economic Sosiety (Cairo: Internasional Association of Islamic Society, 1984). Bisa juga merujuk pada buku Islamic Economics: Theory dan Practice. Sebagai salah satu teks rujukan ekonomi Syariah pertama, Mannan dianugerahi Highest Academic Award of Pakistan pada tahun 1974.

${ }^{4}$ Muhammad Nejatullah Siddiqi, Role of The State in The Ekonomi in Islamic Perspective (UK. The Islamic Foundaition, 1992), h. 69

${ }^{5}$ Monzer Kahf, The Principle of Sosioeconomic Justice in the Contemporary Fiqh of Zakah. Iqtishad Journal of Islamic Economic, Vol I No. I, Muharram $1420 \mathrm{H}$.

${ }^{6}$ Umer Chapra, Islam dan Pembangunan Ekonomi (Jakarta: Gema Insani Press, 2000).

${ }^{7}$ M. Nur Rianto, Pengantar Ekonomi Sayriah Teori dan Praktek (Cet. I; Bnadung: Pustaka Setia, 2015), h. 109-131. 
Musyfikah Ilyas

Pertumbuhan ekonomi syariah yang semakin pesat dan kompleks, menghasilkan produk ekonomi syariah yang beragam, meningkatnya kerjasama ekonomi, tentu berimbas pada penyebab semakin rentangnya penyebab konflik atau sengketa ekonomi syariah. Sebab terjadinya sengketa ekonomi syariah, diantaranya wanprestasi, perbuatan melawan hukum, kerugian salah satu pihak, adanya pihak yang tidak puas atas tanggapan yang menyebabkan kerugian dan penyebab lainnya dan keadaan memaksa. Tentu saja harapan besar bahwa ekonomi syariah berjalan sesuai dengan prinsip-prinsip syariah, tetapi tidak menutup kemungkinan akan terjadi implikasi yang berbeda dengan yang diharapkan dan untuk mengatasinya perlu ada aturan yang jelas dan pasti agar jalan penyelesaian sengketa mampu memberikan kepastian hukum bagi semua pihak.

Penyelesaian sengketa ekonomi syariah telah diatur setidaknya ada dua pilihan penyelesaian sengketa, pertama, penyelesian sengketa ekonomi syariah jalur litigasi yakni penyelesaian sengketa yang diselesaikan melalui lembaga pengadilan dengan berbagai hukum acaranya,. kedua penyelesian sengketa ekonomi syariah jalur nonlitigasi yakni penyelesaian sengketa yang penyelesaiannya diselesaikan di luar pengadilan sebagai alternatif penyelesaian sengketa meliputi APS (alternative penyelesaian sengketa) atau diistilahkan ADR (alternative dispute resolution), Arbitrase, dan lembaga konsumen. Salah satu bentuk APS sebagai penyelesaian sengketa musyawarah akan dijelaskan secara komprehensif tentang musyawarah dari aspek hukum Islam.

\section{A. METODE PENELITIAN}

Penelitian ini menggunakan literatur pustaka, mengumpulkan data-data yang bersumber dari literatur dan dokumen yang relevan yang kemudian dianalisis dengan menggunakan metode deskriptif dengan pendekatan hukum Islam sehingga persoalan yang menjadi kajian dalam artikel ini akan terjawab yaitu penyelesaian sengketa ekonomi syariah melalui jalur musyawarah.

\section{B. PEMBAHASA}

\section{Pengertian Musayawarah}

Konsep musyawarah merupakan salah satu pesan syariat yang sangat ditekankan di dalam al-Quran keberadaannya dalam berbagai bentuk pola kehidupan manusia, baik dalam bentuk skala kecil yakni rumah tangga yang terdiri anggota kecil keluarga, dan dalam skala besar yakni sebuah negara yang terdiri dari pemimpin dan rakyat, konsep musyawarah merupakan suatu landasan tegaknya kesamaan hak dan kewajiban dalam kehidupan manusia, di mana antara pemimpin dan rakyat memiliki hak yang sama membuat aturan yang mengikat dalam lingkup kehidupan bermasyarakat.

Pentingnya konsep musyawarah sebagai alternatif penyelesaian sengketa ekonomi syariah sangat di tekankan dalam al-Qur'an bahwa konsep musyawarah merupakan tradisi umat muslim pada masa nabi yang harus terus dilestarikan dalam tatanan kehidupan sekaligus merupakan perintah Allah yang disampaikan kepada nabi sebagai salah satu landasan syariah yang harus tetap ditegakan, terutama dalam kehidupan modern saat ini. 
Akar kata musyawarah yang sudah menjadi bahasa Indonesia tersebut adalah شور yang berakar kata sy-wa-ra (ش و ر ) berarti menampakan sesuatu atau mengeluarkan madu dari sarang lebah. ${ }^{8}$ Musyawarah bararti menampakan sesuatu yang semula tersimpan atau mengeluarkan pendapat yang baik kepada pihak lain.

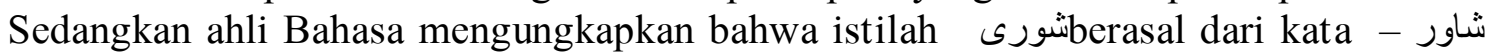
yang berarti menjelaskan, menyatakan atau mengajukan dan mengambil sesuatu, ${ }^{9}$ bentuk lain dari kata kerja ini adalah asyara (memberi isyarat), tasyāwara, (berunding saling tukar pendapat), syawir (pendapat) musyawarah dan mustasyir (minta pendapat orang lain). Jadi syura adalah menjelaskan, menyatakan atau mengajukan pendapat yang baik, di sertai dengan menanggapi dengan baik pula pendapat tersebut untuk mencapai kemaslahatan bersama dengan maksud mencapai putusan atas penyelesaian masalah bersama.

Musyawarah merupakan salah satu prinsip dalam Islam dan manusia diperintahkan Allah swt. untuk melaksanakannya. Karena pentingnya musyawarah dalam Islam, salah satu surah dalam al-Quran surah ke-42 dinamakan asy-syūrā (musyawarah) dalam al-Quran musyawarah terdapat dalam tiga ayat. (1) Q.S. asysyūra (42) ayat 38 dengan menggunakan kata syürā.;

Terjemahan:

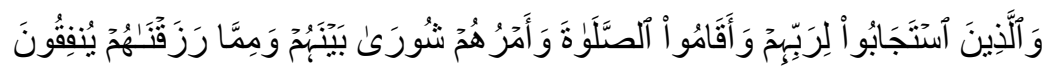

Dan [bagi] orang-orang yang menerima [mematuhi] seruan Tuhannya dan mendirikan shalat, sedang urusan mereka [diputuskan] dengan musyawarat antara mereka; dan mereka menafkahkan sebagian dari rezki yang Kami berikan kepada mereka.

(2) Q.S. al-Baqarah (2) ayat 233 dengan kata tasyāwur

Terjemhan:

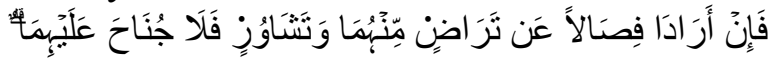

Apabila keduanya ingin menyapih [sebelum dua tahun] dengan kerelaan keduanya dan permusyawaratan, maka tidak ada dosa atas keduanya.

(3) Q.S. ali Imran (3) ayat 159 dengan kata syawir.

Terjemahan:

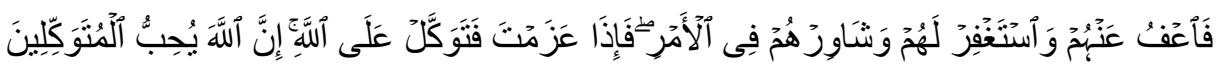

Maka disebabkan rahmat dari Allah-lah kamu berlaku lemah-lembut terhadap mereka. Sekiranya kamu bersikap keras lagi berhati kasar, tentulah mereka menjauhkan diri dari sekelilingmu. Karena itu ma'afkanlah mereka, mohonkanlah ampun bagi mereka, dan bermusyawaratlah dengan mereka dalam urusan itu [1]. Kemudian apabila kamu telah membulatkan tekad, maka bertawakkallah kepada Allah. Sesungguhnya Allah menyukai orang-orang yang bertawakkal kepada-Nya.

\footnotetext{
${ }^{8}$ Abi Al- Husain Ahmad bin Faris, Maqayid al-Lughah, Juz III (t.t: Dar al-Fikr, t.th.), h. 226. Jamaluddin Muhammad Ibn Mukram Ibn al Manzhur al-Afriqiy al-Mishriy, Lisan al-Araby (Bairut: Dar al-Fikr, 1990), h. 434.

${ }^{9}$ Ibrahim Anis, Mu'jam al-Wasith, Juz I (Teheran: Maktabah al-Ilmiah, t.th.), h. 501.
} 
Musyfikah Ilyas

Ketiga ayat itu, surah asy-syūra (42) ayat 38 adalah ayat yang lebih dahulu diturunkan dan termasuk dalam surah Makkiyah) kedua ayat lainnya termasuk dalam surah Madaniyah (diturunkan dalam periode Nabi saw. di Madinah). Surah ali Imran (3) ayat 159 diturunkan ketika berakhirnya Perang Uhud pada tahun ke-3 Hijrah. ${ }^{10}$

Ayat diatas menjelaskan anjuran bermusyawarah sebagai salah satu ajaran mendasar dalam Islam yang harus dipraktekan oleh umat Islam dalam pengembilan keputusan untuk menyelesaian berbagi persoalan umum sehingga dalam persoalan sengketa ekonomi syariah, musyawarah bisa digunakan sebagai sistem dalam penyelesaian sengketa ekonomi syariah.

Sejarah Musyawarah pada masa Rasulullah saw. telah dipraktekkan dalam pengambilan keputusan dan telah dikenal serta membudaya di masyarakat Arab sebelum masa kenabian Muhammad saw. dalam menghadapi setiap persoalan yang menyangkut orang banyak mereka biasanya menghimpun para pemuka kabilah ( $z \bar{u} a s y-$ syüara) untuk bermusyawarah bagi penyelesaiannya. Praktek musyawarah ini terus dilestarikan dan dikembangkan oleh Islam dan dilaksanakan Rasulullah saw. serta para sahabatnya. Salah satu contoh praktek musyawarah yang dijalankan Rasulullah saw. adalah dalam piagam Madinah merupakan perjanjian antara Nabi saw. sebagai pemimpin umat Islam dengan masyarakat Madinah yang terdiri atas suku-suku dan agama yang berbeda terdapat ketentuan yang menjunjung tinggi musyawarah yaitu "Dalam kehidupan kemasyarakatan harus selalu saling bermusyawarah dan menasehati (antara masyarakat Islam dengan Yahudi) dalam kebaikan, bukan dalam perbuatan dosa."

\section{Ruang Lingkup dan Bentuk Musyawarah}

Objek permasalahan yang perlu di musyawarahkan menurut Rasyid Ridha adalah yang menyangkut persoalan keduniawian yang tidak terdapat ketentuannya dalam al-Quran dan sunnah. Permasalahan keagamaan semata-mata sepenuhnya menjadi wewenang Allah swt. melalui firman-Nya dan wewenang Rasulullah saw. melalui sunnahnya. Di luar ruang lingkup itu termasuk bidang ijtihad yang memerlukan musyawarah. Ar-Razi Muhammad Mustafa al-Marāgi, Abu Bakar al-Jassās berpendapat bahwa kata umur dan amr dalam surah asy-Syūrā (42):38 dan Ali Imran (3): 159 menunjuk kepada segala sesuatu yang tidak terat ur secara jelas (eksplisit) oleh al-Quran dan Sunnah. ${ }^{11}$ Oleh karena menurut mereka ruang lingkup persoalan yang menjadi objek musyawarah tidak hanya terbatas pada persoalan duniawi seperti pendapat Rasyid Ridha tetapi meliputi urusan agama yang tidak ada nash nya yang pasti dalam al-Quran dan sunnah. Jadi menurut mereka, yang perlu dimusyawarakan meliputi persoalan duniawi dan agama yang ketentuannya tidak bersifat pasti (qat'i), tetapi relatif (zanni) karena itu ketentuan dan keputusan hasil musyawarah pun bersifat zanni yang bisa diperbaiki atau diubah sesuai dengan kebutuhan dan perkembangan zaman.

\footnotetext{
${ }^{10}$ Abdul Azis Dahlan (ed), Ensiklopedi Hukum Islam, Jilid 4 (Cet. V; Jakarta: Ichtiar van Hoeve, 2001), h. 1263

${ }^{11}$ Abdul Aziz DAhlan (ed), Ensiklopedi Hukum Islam, Jilid 4, h. 1264-1265
} 
Adapun orang-orang yang berhak melakukan musyawarah dalam urusan yang menyangkut kepentingan umum atau masyarakat, dalam literatur hukum Islam dikenal konsep ahl al hall wa al-'aqd (pakar dalam mengambil keputusan dan menyelesaikan masalah). ${ }^{12}$ Bentuk syūrā yang dianjurkan di dalam Al-Quran tidak menjelaskan dalam bentuknya. Pada dasarnya untuk memberi kesempatan kepada setiap masyarakat dan pencari keadilan untuk menyusun bentuk syürā yang mereka inginkan sesuai dengan perkembangan dan ciri masyarakat masing-masing, sehingga musyawarah dapat dijadikan alternatif dalam penyelesaian sengketa dalam berbagai persoalan yang dihadapi oleh masyarakat.

\section{Landasan Hukum Alternatif Penyelesaian Sengketa dalam Bentuk Musyawarah}

Alternatif penyelesaian sengketa (APS) atau dikenal juga dengan alternative dispute resolution (ADR). Meskipun memaknai bahasa yang umum dan holistik. Namun pada prinsipnya alternatif penyelesaian sengketa (APS) tidak dapat secara serta merta mewakili keseluruhan dari jenis dan bentuk penyelesaian sengketa secara nonlitigasi, setidaknya pendapat ini dilandasi oleh beberapa alasan yang cukup kuat. ${ }^{13}$ Setidaknya terdapat dua alasan: pertama, Alternatif Penyelesaian Sengketa (APS) atau dikenal juga dengan Alternative Dispute Resolution (ADR) diatur oleh undang-undang tersendiri yaitu Undang-Undang Nomor 30 Tahun 1999 tentang Arbitrase dan Alternatif Penyelesaian Sengketa., kedua, terdapat peyelesaian sengketa secara nonlitigasi di luar Alternatif Penyelesaian Sengketa (APS) atau Alternative Dispute Resolution (ADR) misalnya penyelesaian sengketa diatur melalui Badan Penyelesaian Sengketa Konsumen (BPSK) yang diatur oleh Undang-Undang Nomor 8 Tahun 1999 tentang Perlindungan Konsumen.

Secara garis besar, alternatif penyelesaian sengketa terdiri dari dua jenis mekanisme, Pertama, dengan sistem musyawarah, yang terdiri dari berbagai bentuk di antaranya mediasi, konsultasi, negosiasi, konsiliasi dan penilaian ahli. Kedua, arbitrase yang terdiri dengan berbagai instrumemnya. Pada umumnya, para pihak menganggap mekanisme penyelesaian melalui jalur nonlitigasi ini adalah awal (first resort). Adapun jalur litigasi baru digunakan manakala upaya penyelesaian nonlitigasi tidak berhasil dilakukan. Menguraikan musyawarah sebagai penyelesaian sengketa ekonomi syariah jalur nonlitigasi sebagai berikut:

\section{Mediasi}

Mediasi merupakan pengelesaian sengketa jalur nonlitigasi melalui proses perundingan para pihak dengan di bantu oleh mediator sebagai perantara ataupun penghubung. Dalam proses mediasi, mediator sebagai penengah dan fasilitator bagi yang berperkara. Mediasi dilakukan berdasarkan Penyelesaian sengketa jalur nonlitigasi dan litigasi ${ }^{14}$ sesuai ketentuan pasal 1 angka (7) PERMA Nomor 1 Tahun 2016 tentang Prosedur Mediasi di Pengadilan. Mediasi dalam sengketa ekonomi Syariah terdapat lima tahapan yakni kedua belah pihak sepakat menempuh proses

\footnotetext{
${ }^{12}$ Abdul Azis Dahlan (ed), Ensiklopedi Hukum Islam, Jilid 4, h. 1264

${ }^{13}$ Amran Saudi, Penyelesaian Sengketa Ekonomi Teori dan Praktik (Cet. I; Jakarta: Kencana, 2017), h. 61

${ }^{14}$ Abdul Mannan, Hukum Ekonomi Syariah dalam Perspektif Kewenangan Peradilan Agama (Cet. III; Jakarta: Kencana, 2016), h. 450. Mardani, Hukum Ekonomi Syariah di Indonesia (Cet. I; Bandung: PT Refika Aditama, 2011), h. 109-110
} 
Musyfikah Ilyas

mediasi., memahami konflik yang menjadi permasalahan., membangkitkan pilihanpilihan pemecahan masalah., mencapai kesepakatan dan melaksanakan kesepakatan. Mediasi memberikan jalan mudah menyelesaian konflik yang disebabkan oleh sengketa ekonomi syariah yang terjadi di Masyarakat.

\section{Konsultasi}

Konsultasi merupakan suatu tindakan yang bersifat personal antara suatu pihak (klien) dan pihak lain yang merupakan konsultan, yang memberikan pendapatnya atau saran kepada klien tersebut untuk memenuhi keperluan dan kebutuhan klien. Konsultan hanya memberikan pendapat (hukum) kepada klien dan selanjutnya keputusan mengenai penyelesaian sengketa ekonomi syariah jalur nonlitigasi di serahkankan kepada para pihak. ${ }^{15}$

Asas konseling memiliki beberapa etika yang dijadikan sebagai dasar untuk melakukan konsultasi, dasar konsultasi tersebut dijadikan pertimbangan. Asas lain yang bisa digunakan dalam konsultasi, diantaranya: ${ }^{16}$

1) Asas Kerahasiaan

Menjaga rahasia pihak berperkara sebagai bentuk penghargaan sehingga dapat menimbulkan rasa aman, menghilangkan kekhawatiran penyalahgunaan rahasia dan kepercayaan yang diberikan kepada konsultan.

2) Asas Kesukarelaan

Proses konsultasi tidak mengandung unsur paksaan, dan membutuhkan kerjasama yang demokratis antara konsultan dan pihak berperkara. Kerjasama akan terjalin jika dengan suka rela dan terbuka menjelaskan masalah yang dihadapinya.

3) Asas Kemandirian

Pada akhir konsultasi, dan konsultan telah menjelaskan pendapat hukumnya, maka selanjutya keputusan tetap diserahkan kepada para pihak.

\section{Negosiasi}

Negosiasi merupakan cara penyelesaian sengketa jalur nonlitigasi, antara dua orang yang berperkara atau lebih untuk dikompromikan atau tawar-menawar kepentingan dalam menyelesaikan perkara untuk mencapai kesepakatan bersama. ${ }^{17}$

Mencapai kesepakatan yang diharapkan maka perlu memperhatikan beberapa hal dalam bernegosiasi yakni: memahami tujuan yang ingin dicapai; menguasai materi yang akan dinegosiasikan; memahami tujuan dari negosiasi itu sendiri; dan memahami keterampilan teknis bernegosiasi.

Proses negosiasi tidak terikat secara formal dan apabila berhasil mencapai kesepakatan, maka para pihak membuat kesepakatan secara tertulis berupa akta perdamaian yang ditandatangani oleh kedua belah pihak yang berperkara dan kemudian didaftarkan di pengadilan dengan tenggang waktu 30 hari sejak kesepakatan tersebut ditandatangani.

\footnotetext{
${ }^{15}$ Abdul Mannan, Hukum Ekonomi Syariah dalam Perspektif Kewenangan Peradilan Agama, h. 442

${ }^{16}$ Hallen A, Bimbingan dan Konseling (Cet. I; Jakarta: Ciputat Press, 2002), h. 66-74

${ }^{17}$ Abdul Mannan, Hukum Ekonomi Syariah dalam Perspektif Kewenangan Peradilan Agama, h. 442-445.
} 
Ketentuan negosiasi di atur pada Pasal 6 ayat (2), (6) dan (7) Undang-Undang Nomor 30 Tahun 1999 tentang Arbitrase dan Alternatif Penyelesaian Sengketa, sebagai dasar untuk mendapatkan pengesahan. Penyelesaian sengketa jalur nonlitigasi dengan menggunakan negosiasi berdasarkan ketentuan umum dalam Q.S. an-Nisa 135

Terjemahan:

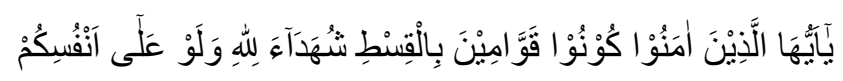

Hai Orang-orang beriman, jadilah kamu orang yang benar-benar penegak keadilan, menjadi saksi karena Allah biarpun terhadap dirimu sendiri.

Proses kreatif dalam menyelesaiakan sengketa ekonomi syariah dengan menggunakan negosiasi dengan mempertemukan pihak-pihak dengan modelnya sendiri terhadap apa yang akan dicapai. Kunci yang harus diperhatikan dalam negosiasi: pertama, menangkap kesempatan, kesempatan dalam menyelesaikan sengketa ekonomi syariah dengan model-model yang ideal dalam penyelesaian sengketa ekonomi syariah di buat sendiri oleh para pihak yang berperkara dan menyatukannya dalam bentuk negosiasi. Kedua, pentingnya kepercayaan, keberhasilan negosiasi tergantung pada pihak yang bersengketa pada saat melakukan negosiasi, sehingga dalam bernegosiasi sangat dibutuhkan kepercayaan para pihak. Ketiga, Fleksibelitas, proses negosiasi yang membutuhkan kesepakatan dalam memenuhi kepentingan para pihak, tentu harus sefleksibel mungkin, untuk menghadapi kemungkinan di masa yang akan datang.

Negosiasi merupakan saah satu cara yang paling aman, cepat, tepat, dan convidensial dalam menyelesaikan sengketa ekonomi syariah jalur nonlitigasi karena tidak melibatkan pihak ketiga dalam penyelesaiannya dan para pihak membuat sistem komunikasi dan membuat model-model kesepakatan sendiri untuk mencapai kesepakataan yang memihak kepentingan para pihak berperkara.

\section{Konsiliasi}

Usaha perdamaian dengan menggunakan pihak ketiga yang disebut konsiliator dengan mengupayakan pertemuan diantara pihak yang berselisih, pertemuan konsiliasi bisa juga disebut pertemuan suka rela. konsiliator biasanya tidak terlibat secara mendalam atas subtansi dari perselisihan dan pertemuan konsiliasi dapat berupa permintaan maaf, perubahan kebijaksanaan dan kebiasaan, memeriksa kembali prosedur pekerjaan, mempekerjakan kembali, ganti rugi uang dan sebagainya.

Konsiliasi diatur dalam ketentuan pasal 1 ayat (10) Undang-Undang Nomor 30 Tahun 1999 tentang Arbitrase dan Alternatif Penyelesaian Sengketa memuat penjelasan konsiliasi sebagai salah satu cara yang yang digunakan para pihak yang bersengketa sebagai jalan menyelesaikan sengketa.

Hasil dari kesepakatan kedua pihak melalui konsiliasi harus dibuat secara tertulis dan ditanda tangani secara bersama oleh para pihak yang bersengketa, dan didaftarkan di Pengadilan Agama. Kesepakatan tertulis dari konsiliasi bersifat final dan mengikat.

\section{Penilaian Ahli}

Dasar ketentuan tentang penilaian ahli berdasarkan pada Pasal 1 angka (10) dan Pasal 6 ayat (3) Undang-Undang Nomor 30 Tahun 1999 tentang Arbitrase dan Alternatif Penyelesian Sengketa EKonomi Syariah. Berdasarkan aturan diatas maka 
Musyfikah Ilyas

penilaian ahli bisa dijadikan sebagai alternatife penyelesaian sengketa ekonomi syariah dengan meminta bantuan berupa nasihat ahli dan memuat pendapatpendapatnya yang nantinya dijadikan acuan dalam menyelesaian perkara para pihak yang berperkara untuk mencapai kesepakatan bersama. ${ }^{18}$ Selanjutnya kesepakatan tersebut dituangkan dalam bentuk akta kesepakatan perdamaian.

Musyawarah sebagai cara dalam menyelesaikan permasalahan hendaknya melalui dengan proses musyawarah dengan mengutamakan pertimbangan moral dan bersumber dari hati nurani yang luhur. Sedapat mungkin usul atau pendapat mudah untuk dipelajari, dilakukan atau bahkan hasilnya dilaksanakan nantinya, yang dibicarakan harus diterima akal sehat dan tidak menyusahkan. Dan hasil musyawarah sesuai dengan kepentingan bersama yang mendatangkan kemaslahatan.

Hal-hal yang harus diperhatikan dalam proses musyawarah saling memahami apa yang sedang dimusyawarahkan untuk mengambil keputusan sehingga mendatangkan kemaslahatan dan jika menghasilkan putusan dalam bermusyawarah, maka menerima hasil put usan yang sudah diambil adalah keput usan yang terbaik.

Menerima masukan masukan dalam bentuk kritik, usul maupun saran dalam bermusyawarah karena tidak ada unsur pemaksaan dalam mengambil suatu keputusan sehingga dibutuhkan saling memahami dan menghargai pendapat dari orang lain. Jika nantinya kemungkinannya tidak didapatkan pendapat yang baik atau tidak menguntungkan bagi kedua pihak yang bersengketa atau beberapa pendapat dianggap sama baiknya maka jalan ditempuh adalah mencari pendapat yang paling mendatangkan kemaslahatan.

Musyawarah jika ditilik dari berbagai hukum baik dalam hukum Islam maupun hukum positif tidak ada yang menjelaskan sistemnya secara mendetail sehingga para yang berperkara bisa mengambil cara atau bentuk baru dalam musyawarah dalam menyelesaikan sengketa ekonomi syariah, beberapa yang diuraikan diatas hanya sebagian saja sehingga bentuk musyawarah apapun selama tidak bertentangan dengan syarait Islam bisa digunakan selama mendatangkan kemaslahatan.

Manfaat Musyawarah sebagai Alternatif Penyelesaian Sengketa Nonlitigasi

1. Sistem penyelesaian sengketa dengan bersifat informal, sederhana dan fleksibel.

2. Menggunakan biaya yang ringan karena penyelesaian sengketa ekonomi syariah diselesaikan oleh pihak yang berperkara sendiri.

3. Kemenangan didapatkan dari kedua belah pihak sehingga tetap terjalin silahturahmi demi terwujudnya keadilan sosial rahmatan lil alamin.

4. Para pihak menyelesaikan konflik dengan baik dan hasilnya dapat diterima oleh kedua pihak yang bersengketa.

Alternatif penyelesaian sengketa ekonomi syariah jalur nonlitigasi dalam bentuk musyawarah berdasarkan uraian di atas merupakan cara yang paling sederhana, aman, hemat biaya dan waktu, fleksibel, dan terjangkau tanpa harus melibatkan pengadilan sebagai solusi awal dalam menyelesaian sengketa ekonomi syariah.

\footnotetext{
${ }^{18}$ Abdul Mannan, Hukum Ekonomi Syariah dalam Perspektif Kewenangan Peradilan Agama, h.
} 459. 


\section{PENUTUP}

\section{Kesimpulan}

Penyelesaian sengketa ekonomi syariah jalur nonlitigasi salah satu jenis mekanisme penyelesaian sengketa yakni sistem musyawarah. Sebagai langkah awal dan cara yang paling mudah, efektif, efesien dalam mengatasi konflik, sejalan anjuran dalam al-Quran dan sunnah. Musyawarah dapat menjadi aternatif solusi penyelesaian sengketa ekonomi syariah yang dianggap sesuai dengan karakter dan kepribadian masyarakat Indonesia.

\section{Implikasi}

Menawarkan dan mengedepankan musyawarah untuk menyelesaikan sengketa ekonomi syariah. Memberikan saran dan pertimbangan kepada pihak yang berkonflik untuk menyelesaikan dengan jalan musyawarah. Dan mengembalikan kepercayaan masyarakat untuk mengaktualisasikan ajaran agamanya yang menjunjung tinggi konsep musyawarah dalam menghadapi berbagai persoalan hidup dan kehidupan yang semakin kompleks dan rumit sehingga dapat mendatangkan maslahat dalam kehidupan bermasyarakat, berbangsa dan bernegara.

\section{DAFTAR PUSTAKA}

Abi Al- Husain Ahmad bin Faris, Maqayid al-Lughah, Juz III. t.t: Dar al-Fikr, t.th.

Ali, Zainuddin. Hukum Ekonomi Syariah. Cet. II; Jakarta: Sinar Grafika, 2008.

Abdul Azis Dahlan (ed), Ensiklopedi Hukum Islam, Jilid 4. Cet. V; Jakarta: Ichtiar van Hoeve, 2001.

Anis, Ibrahim. Mu'jam al-Wasith, Juz I. Teheran: Maktabah al-Ilmiah, t.th.

Chapra, Umer. Islam dan Pembangunan Ekonomi. Jakarta: Gema Insani Press, 2000.

Haneef, M. Aslam. Pemikiran Ekonomi Islam Kontemporer. Jakarta: Rajawali Press, 2010.

Hallen A, Bimbingan dan Konseling. Cet. I; Jakarta: Ciputat Press, 2002.

Jamaluddin Muhammad Ibn Mukram Ibn al Manzhur al-Afriqiy al-Mishriy, Lisan alAraby. Bairut: Dar al-Fikr, 1990.

Kahf, Monzer. The Principle of Sosioeconomic Justice in the Contemporary Fiqh of Zakah. Iqtishad Journal of Islamic Economic, Vol I No. I, Muharram 1420 H.

Mannan, M. Abdul. The Making of An Islamic Economic Sosiety. Cairo: Internasional Association of Islamic Society, 1984.

Mannan, Abdul, Hukum Ekonomi Syariah dalam Perspektif Kewenangan Peradilan Agama. Cet. III; Jakarta: Kencana, 2016.

Rianto, M. Nur. Pengantar Ekonomi Sayriah Teori dan Praktek. Cet. I; Bnadung: Pustaka Setia, 2015.

Siddiqi, Muhammad Nejatullah. Role of The State in The Ekonomi in Islamic Perspective. UK. The Islamic Foundaition, 1992.

Saudi, Amran. Penyelesaian Sengketa Ekonomi Teori dan Praktik . Cet. I; Jakarta: Kencana, 2017.

Mardani, Hukum Ekonomi Syariah di Indonesia . Cet. I; Bandung: PT Refika Aditama, 2011. 